\title{
Article
}

\section{Life Cycle Analysis of Road Construction and Use}

\author{
Giampiero Trunzo, Laura Moretti 1 and Antonio D'Andrea * \\ Department of Civil, Construction and Environmental Engineering, Sapienza University of Rome, 00184 Rome, \\ Italy; trunzo.1308433@studenti.uniroma1.it (G.T.); laura.moretti@uniroma1.it (L.M.) \\ * Correspondence: antonio.dandrea@uniroma1.it; Tel.: +39-06-44585116
}

Received: 17 December 2018; Accepted: 9 January 2019; Published: 13 January 2019

check for updates

\begin{abstract}
Both the construction and use of roads have a range of environmental impacts; therefore, it is important to assess the sources of their burdens to adopt correct mitigation policies. Life cycle analysis (LCA) is a useful method to obtain demonstrable, accurate and non-misleading information for decision-making experts. The study presents a "cradle to gate with options" LCA of a provincial road during 60 year-service life. Input data derive from the bill of quantity of the project and their impacts have been evaluated according to the European standard EN 15804. The study considers the impacts of the construction and maintenance stages, lighting, and use of the vehicles on the built road. The results obtained from a SimaPro model highlight that the almost half of impacts took place during the construction stage rather than the use stage. Therefore, the adoption of environmentally friendly road planning procedures, the use of low-impact procedures in the production of materials, and the use of secondary raw materials could have the largest potential for reducing environmental impacts.
\end{abstract}

Keywords: road construction; impact category; tunnel; bridge; embankment; trench; life cycle analysis

\section{Introduction}

In recent years, environmental aspects related to road infrastructure construction have increasingly come under examination [1,2] in order to apply environmental award criteria in calls for tender [3] and introduce the green public procurement (GPP). At the international level, several efforts have been made to apply GPP to the road sector: in Sweden, environmental aspects are integrated in road maintenance contracts [4-6]; in Finland, procurement methods are implemented to reduce the environmental impacts of roads [7]; in the Netherlands, GPP has been implemented to manage the main road network [8].

Currently, the Italian Ministry of the Environment is transposing the meaning of the document "Green Public Procurement Criteria for Road Design, Construction and Maintenance" published in 2016 by the European Union [9] to encourage the purchasing of products, services and works with reduced environmental impacts. Four criteria are proposed to assess the life cycle impacts of road construction: Life Cycle Impact Assessment (LCIA), Carbon footprint (CF), recycled and re-used content, and Low emissions from transport of heavy materials. The listed criteria have decreasing levels of ambition and technical complexity: in literature the most frequently adopted frameworks are LCIA and CF [10-13]. LCIA is a holistic assessment tool which considers different environmental impacts (e.g., acidification, eutrophication, abiotic depletion), while CF only evaluates the total amount of greenhouse gas emissions of road processes: CF is the result of a partial LCIA implementation. Recycled and re-used content and low emissions from transport of heavy materials focus respectively on the content of used recycled, re-used or by-products materials, and on $\mathrm{CO}_{2}$ emissions from the transportation of aggregates. These last two approaches are alternatives to LCIA and $\mathrm{CF}$, and it is recommended to combine both in order to achieve an overall environmental benefit. According to the EU environmental objectives and data available in the literature, authors adopted the 
LCIA because it allows a quantitative and robust evaluation of each examined process [14]. Indeed, the unbiased and comparable results from LCIA depend on the specific production chain, it takes into account the specific boundary system and operational conditions, and could be adopted as an effective environmental decision support system [15]. Since the early 2000s, some research has used the life cycle assessment methodology to assess the environmental performances of a road and its different stages. With different analysis periods and functional units, they examined the environmental impacts of road materials [16-20] and compared construction techniques and maintenance activities [10,21-25] with different methods and software. Marzouk et al. [21] used the software Copert 4 [26] to assess the overall environmental impacts and primary energy associated with earthwork and pavement processes. Hammervold [22] applied the impact assessment method ReCiPe [27] to construction and maintenance activities of two highway projects in southern Norway in order to identify the main aspects affecting LCA results. Burdens of traffic are not considered. According to EN 15804 [28], Moretti et al. [23] assessed the environmental and human health impact of construction of two different road cross-sections (i.e., embankment and trench sections). Sayagh et al. [24] used the tool ERM (elementary road modulus) [29], to assess LCA of construction and maintenance activities three different road pavements. The EU project ECRPD [25] assessed impacts of wearing layers during their construction and maintenance, whereas initial phases of road and pavement construction (e.g., subgrade preparation and subbase construction) were excluded.

Conversely, this study aims to assess, according to the standard EN 15804 "Sustainability of construction works, environmental product declarations, core rules for the product category of construction products" [28] the environmental impacts of construction and use of a provincial road in Central Italy. The analysis starts considering the input data from the bill of quantity of the project: it considers all materials, works and processes needed to have the final product: "the road". Moreover, the analysis examines the use stage of the road during 60-year service life until its exceptional maintenance of structures occurs: all impacts from traffic and routine maintenance are assessed. The importance of this work is that it provides reliable LCIA results of the environmental impacts of construction and use of a real road. The interpretation of the results allows the identification of the majority of impacting processes currently used in this sector, in order to reduce its burdens and to develop an environmentally aware public procurement policy.

\section{Materials and Methods}

In this study, the LCIA methodology has been implemented to assess the environmental impacts of construction and use of an $8.5 \mathrm{~km}$-long provincial road during 60 year-service life. The examined road offers a solution to the local and touristic traffic between two densely populated towns. Figure 1 represents the cross-section of the analyzed infrastructure: it is composed of two $1.25 \mathrm{~m}$ wide shoulders and two $3.50 \mathrm{~m}$ wide lanes.

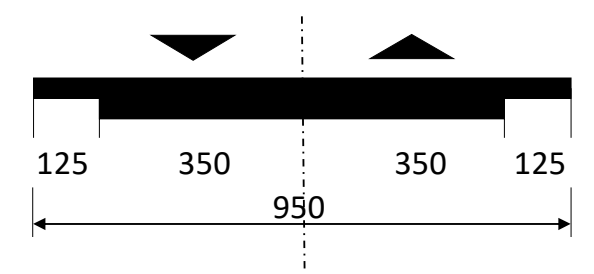

Figure 1. Design cross section (unit of measure: $\mathrm{cm}$ ).

The road is in a mountainous region of central Italy, where the Appennine mountains are located. The territory morphology seriously affects the altimetric design of the infrastructure, whose $16.6 \%$ in length is raised on above- and under-grade structures. Indeed, the road is composed of:

- $\quad 7.1 \mathrm{~km}$-long open road sections (not more than $5 \mathrm{~m}$-high trench or embankment cross-sections);

- $0.3 \mathrm{~km}$-long 4-span new bridge with reinforced-concrete slab on three U-shaped precast reinforced-concrete beams; 
- $1.1 \mathrm{~km}$ of new single-tube tunnel built with mechanized excavation. According to the geological condition, one part of the rock is granite and the other one is shale. In the joint part the overlying bedrock thickness is approximately $200 \mathrm{~m}$. Water inflows were expected when tunnel excavation approached the joint of two rocks. Therefore, foam consolidation and grouting method were designed to control the displacement of the rock and its supports.

Geometrical and functional issues were adopted for the road design to comply with the current Italian requirements for the construction of minor highways [30]; for the first 20 years of service life, the design traffic consists of the number of passes listed in Table 1.

Table 1. Passes of vehicles within the first 20 years of service life.

\begin{tabular}{ccc}
\hline Vehicle Type & Maximum Mass (t) & Number of Passes \\
\hline Commercial and heavy vehicles & 56 & $1,500,000$ \\
Cars & 3 & $15,000,000$ \\
Mopeds & 0.5 & 189,000 \\
\hline
\end{tabular}

Table 2 lists the traffic spectrum of commercial and heavy vehicles within the first 20 years of service life.

Table 2. Traffic spectrum within the first 20 years of service life.

\begin{tabular}{ccc}
\hline Vehicle Code & Maximum Mass (t) & Number of Passes during the Service Life \\
\hline$V_{1}$ & 12 & 882,000 \\
$V_{2}$ & 16 & 441,000 \\
$V_{3}$ & 26 & 88,500 \\
$V_{4}$ & 36 & 42,000 \\
$V_{5}$ & 56 & 3000 \\
$V_{6}$ & 13 & 43,500 \\
\hline
\end{tabular}

Given a subgrade resilient modulus equal to $90 \mathrm{MPa}$, and the traffic data in Tables 1 and 2, for a 20-year service life the flexible pavement is composed of [31]:

- $3 \mathrm{~cm}$-thick asphalt wearing course;

- $5 \mathrm{~cm}$-thick asphalt binder course;

- $12 \mathrm{~cm}$-thick asphalt base course;

- $30 \mathrm{~cm}$-thick cement-stabilized sub-base.

In order to assess the impacts of construction and use of the road for 60 years, the authors assumed that traffic volume and spectrum do not change during the overall reference service life.

The bill of quantity, which is not disclosed herein, due to privacy reasons, allowed the identification of works and materials needed for the road construction. These data constituted the Life Cycle Inventory (LCI) and they were modeled according to the characterization factors listed in EN 15804:2012+A1:2013 [28] in order to calculate the Life Cycle Impact Assessment (LCIA). The characterization factors allow for comparing the ability of different substances to cause the same environmental impact because they convert the results from LCI into a common unit of a category indicator, expressed as equivalent (eq.), (Equation (1)):

$$
I C=\sum_{x} C F_{i c}(x) \cdot \operatorname{INV}(x)
$$

where IC is the Impact Category, obtained from the inventory of the substance $x, \operatorname{INV}(x)$, and $C F_{i c}(x)$ is the characterization factor assigned to the substance $x$ for the calculation of IC. 
The database Ecoinvent 3.1 [32], integrated in the software package SimaPro 8.0.5.13 [33], was used to assess the impact categories listed in Table 3. These parameters describe the environmental impacts according to the EN 15804 [28].

Table 3. Impact categories considered in the LCA.

\begin{tabular}{ccc}
\hline Impact Category & IC & Unit of Measure \\
\hline Global Warming Potential & $G W P$ & $\mathrm{~kg} \mathrm{CO}_{2}$ eq. \\
Ozone layer Depletion Potential & $O D P$ & $\mathrm{~kg} \mathrm{CFC11-eq.}^{-}$ \\
Acidification Potential of soil and water & $A P$ & $\mathrm{~kg} \mathrm{SO}_{2}$ eq. \\
Eutrophication Potential & $E P$ & $\mathrm{~kg} \mathrm{PO}_{4}^{3-}$ eq. \\
Photochemical Ozone Creation Potential & $P O C P$ & $\mathrm{~kg} \mathrm{C}_{2} \mathrm{H}_{4}$ eq. \\
Depletion of abiotic resources-elements & $A D P-E$ & $\mathrm{~kg} \mathrm{Sb}$ eq. \\
Depletion of abiotic resources-fossil fuels & $A D P-F$ & $\mathrm{MJ}$ \\
\hline
\end{tabular}

The LCIA was carried out according to the standard EN 15804: for each impact category, the study evaluated the overall impact of road construction and/or use, and the partial contributions of four different stages:

1. stage A1: extraction and processing of raw materials, reuse of products or materials from a previous production system, processing of secondary materials used as input, and generation of electricity, steam and heat from primary energy resources, including their extraction, refining and transport;

2. stage A2: transportation of materials and machines to production and construction site;

3. stage A3: in-situ works for road construction (e.g., use of dumpers, graders, lighting installation, waste processing; on-site operations to the road, etc.);

4. stage A4: use of the road (i.e., environmental impacts due to the expected traffic, pavement maintenance, and tunnel lighting).

Figure 2 represents the flow diagram of the phases involved in the "from cradle to gate with options" LCIA.

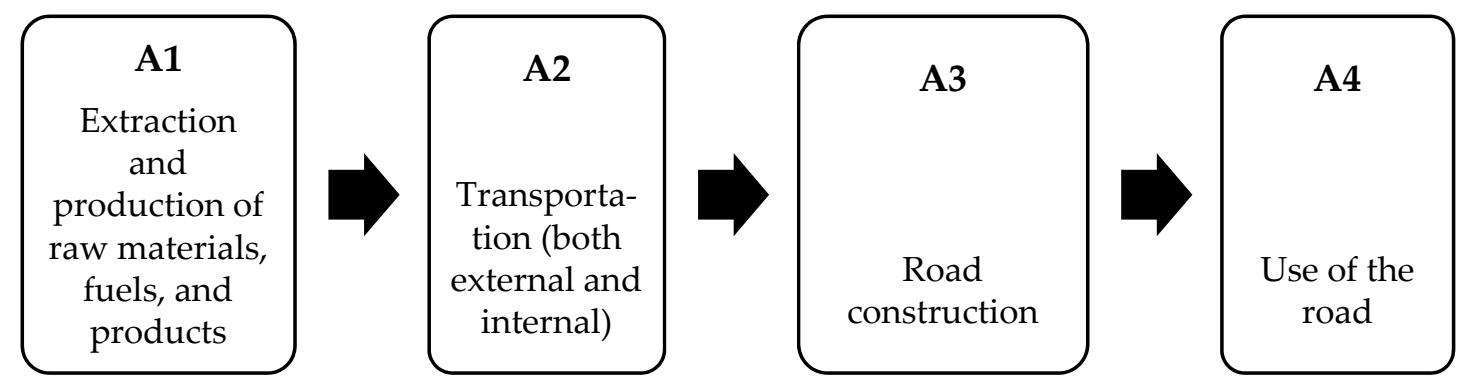

Figure 2. Flow diagram of the phases (or modules) involved in LCIA.

For pavement maintenance, the authors assumed preventive works according to Table 4 [34] for the first 20 years. At the end of 20th year, the pavement will be demolished, rebuilt and maintained according to Table 4.

Table 4. Pavement maintenance.

\begin{tabular}{ccc}
\hline Type of Maintenance & Year & Extension \\
\hline Wearing + binder course milling and patching & 3 & $1 \%$ lanes' surface \\
Wearing course milling and re-construction & 6 & $100 \%$ lanes + shoulders surface \\
Wearing + binder course milling and patching & 9 & $2 \%$ lanes' surface \\
Wearing + binder course milling and re-construction & 12 & $100 \%$ lanes + shoulders surface \\
\hline
\end{tabular}


For tunnel lighting, the authors derived data from previous studies [35,36]. Therefore, the lighting system complies with the requirements laid down by the Italian Organization for Standardization [37-40]. Particularly, the standard UNI 11095 [37] divides the longitudinal section of the tunnel in five reference zones (i.e., access, threshold, transition, interior and exit zones). Each zone differs for the minimum luminance value to be ensured as consequence of the design speed, the meteorological visibility distance, the horizontal lighting in the access zone, the natural luminance, and the optics type. As consequence of different daylight conditions, the tunnel lighting system is composed of one permanent and seven reinforcement installations. Lighting Emission Diode (LED) devices are installed, and they are arranged in a single line in permanent lighting, or in a quincunx geometric pattern in the reinforcement system. Table 5 lists details about the lighting system for each 20-year period of service life.

Table 5. Lighting design data.

\begin{tabular}{cc}
\hline Lighting Data & Value \\
\hline Total installed power $(\mathrm{W})$ & 84,295 \\
Annual consumption $(\mathrm{kWh})$ & 59,500 \\
\hline
\end{tabular}

Table 6 lists the routine maintenance program for the lighting system.

Table 6. Routine maintenance program for the lighting system.

\begin{tabular}{cc}
\hline Type of Work & Frequency \\
\hline Replacing of lamps & once every 10 years \\
Cleaning of lamps & once every 2.5 years \\
\hline
\end{tabular}

For maintenance of structures (e.g., the bridge and the tunnel), the authors assumed the routine maintenance program listed in Table 7.

Table 7. Routine maintenance program for structures.

\begin{tabular}{ccc}
\hline Structure & Type of Work & Frequency \\
\hline \multirow{4}{*}{ Bridge } & Deck and crack sealing & Clean and flush drains \\
& Clean and reseal deck joints & once every 3 years \\
& once every 2 years \\
& Exposed steel cleaning and repainting & once every 5 years \\
& Remove, replace, repair tiles and spalls & once every 2 years \\
\hline \multirow{3}{*}{ Tunnel } & Wash tunnel walls and ceiling & once every 1 year \\
& Repair or replace deteriorated or failed joints & once every 2 years \\
& Clean and seal exposed bars & once every 4 years \\
\hline
\end{tabular}

In order to analyze the effect of the examined stages and identify the most critical works, materials or processes, a sensitivity analysis was carried out. At this purpose, the authors assumed all processes would have a period of less than 20 years occur in cyclic form during the overall service life.

\section{Results}

The A1 to A3 LCIA results for the examined road are listed in Table 8. They refer only to the materials and processes needed for road construction, as required by the project. All construction materials are transported to the road site over distances no greater than $25 \mathrm{~km}$. 
Table 8. LCIA-A1 to A3 phases.

\begin{tabular}{cccc}
\hline IC & Impact Category & Value & Unit of Measure \\
\hline$G W P$ & Global Warming Potential & $3.58 \times 10^{8}$ & $\mathrm{~kg} \mathrm{CO}_{2}$ eq. \\
ODP & Ozone layer Depletion Potential & 48.38 & $\mathrm{~kg} \mathrm{CFC11-eq.}^{6}$ \\
$A P$ & Acidification Potential of soil and water & $1.37 \times 10^{6}$ & $\mathrm{~kg} \mathrm{SO}_{2}$ eq. \\
$E P$ & Eutrophication Potential & $3.94 \times 10^{5}$ & $\mathrm{~kg} \mathrm{PO}_{4}^{3-}$ eq. \\
$P O C P$ & Photochemical Ozone Creation Potential & $3.03 \times 10^{5}$ & $\mathrm{~kg} \mathrm{C}_{2} \mathrm{H}_{4}$ eq. \\
$A D P-E$ & Depletion of abiotic resources-elements & 37.34 & $\mathrm{~kg} \mathrm{Sb} \mathrm{eq.}$ \\
$A D P-F$ & Depletion of abiotic resources-fossil fuels & $3.44 \times 10^{9}$ & $\mathrm{MJ}$ \\
\hline
\end{tabular}

The bar graph in Figure 3 shows the percentage contribution between phases of road construction.

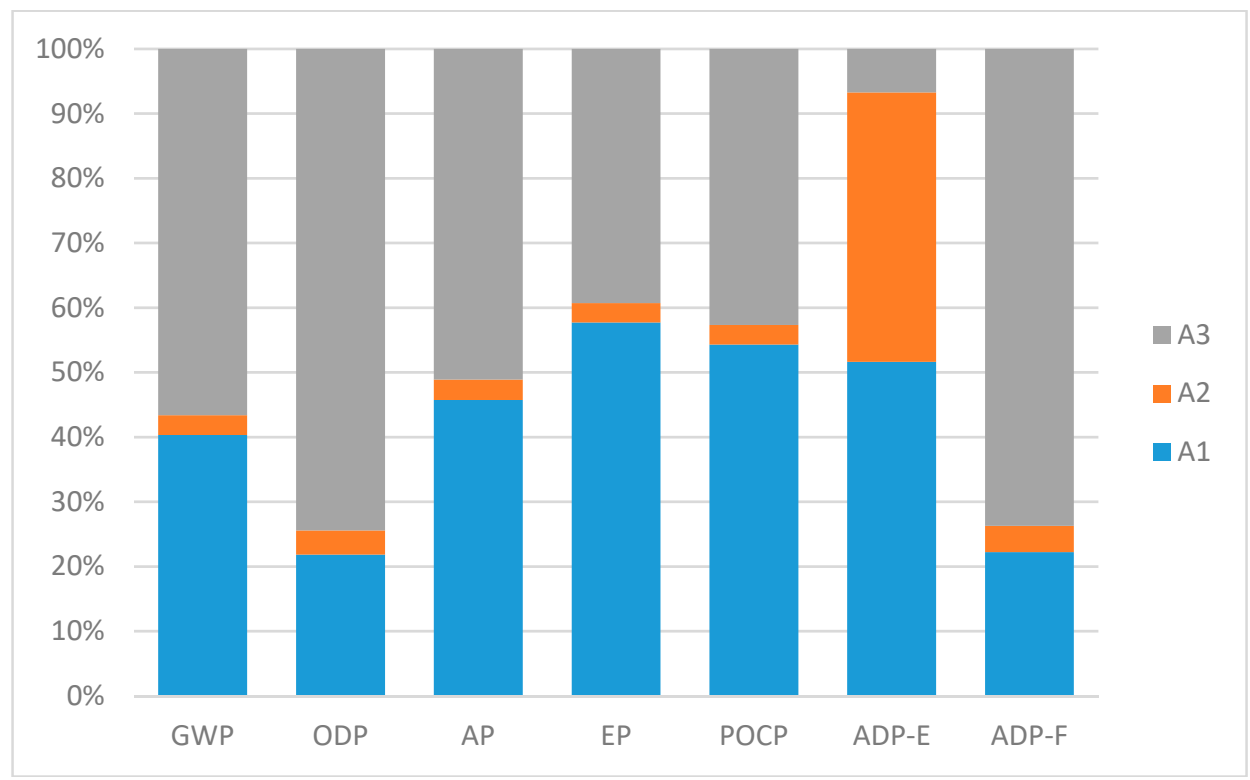

Figure 3. Environmental performances-A1 to A3 phases.

Four main observations can be extracted from Table 7 and Figure 3:

- in the "from cradle to use" analysis, the most impacting phases are A1 and A3: except for ADP-E, they account on average for more than $90 \%$ of total burdens;

- $\quad$ in the phase A1, ODP and ADP-F have the lowest contribution (i.e., $22 \%$ ), while EP and POCP have the highest contributions (i.e., $58 \%$ and $54 \%$, respectively);

- transportation (both external and internal) is the phase which implies the lowest contribution: A2 is on average $3.2 \%$;

- $\quad$ in the phase $\mathrm{A} 3, A D P-F$ and $O D P$ give the highest contributions (on average $74.5 \%$ ).

For each impact category, the authors examined the ten most impacting items, which contribute to more than $92 \%$ of the totals:

- for GWP, diesel machines for earth moving, tunnel excavation and cement grouting cause $1.99 \times 10^{8} \mathrm{~kg} \mathrm{CO}_{2}$ eq. (i.e., $53 \%$ of the overall impact). Aggregates, concrete, reinforcing steel, and lime mortar cause $38 \%$ of the overall impact; the most impacting freight transport (used for transport of cement concrete up to the roadwork site) causes emissions of $3.50 \times 10^{6} \mathrm{~kg} \mathrm{CO}_{2}$ eq. (i.e., $1 \%$ of total GWP);

- for $O D P$ and $A D P-F$, diesel machines for earth moving, tunnel excavation, and cement grouting cause $70 \%$ and $69 \%$ of the overall impacts, respectively. Aggregates, concrete, reinforcing steel, and lime mortar cause $19 \%$ and $20 \%$ of the overall impact, respectively; the most impacting freight 
transport (used for transport of cement concrete up to the roadwork site) causes respectively emissions of $6.03 \times 10^{-1} \mathrm{~kg} \mathrm{CFC}-11$ eq. and $4.17 \times 10^{7} \mathrm{MJ}$, (i.e., $1 \%$ of total ODP and $1 \%$ of total $A D P-F)$;

- for $A P$, diesel machines for earth moving, tunnel excavation, and cement grouting cause $6.89 \mathrm{~kg}$ $\mathrm{SO}_{2}$ eq. (i.e $48 \%$ of total $A P$ ). Aggregates, concrete, reinforcing steel, and lime mortar cause $43 \%$ of the overall impact. Freight transport contributions do not rank in the top ten items: the first one's contribution is related to transport of cement concrete up to the roadwork site and represents $1 \%$ of total $A P$;

- for $E P$ and $P O C P$, diesel machines for earth moving machines and cement grouting cause respectively $37 \%$ and $40 \%$ of the overall impacts, respectively. Aggregates, concrete, reinforcing steel, and lime mortar cause respectively $54 \%$ and $51 \%$ of the overall impact. For both ICs, transport of granular materials is $1 \%$ of total impact (i.e., $3.36 \times 10^{6} \mathrm{~kg} \mathrm{PO}_{4}{ }^{3-}$ eq. and $2.93 \times 10^{3} \mathrm{~kg} \mathrm{C}_{2} \mathrm{H}_{4}$ eq., respectively);

- $\quad A D P-E$ is the impact category with the lowest contribution of earth moving machines (i.e., $32 \%$ ), while construction materials account for $48 \%$ of total consumption of abiotic depletion for non-fossil resources. The most impacting transport items (transport of cement concrete and granular materials up to the roadwork site) imply $6 \%$ of the overall impact.

The analysis of the ten most impacting items for each IC highlights the need for adopting strategies to reduce the impacts of tunnel excavation, road materials production and excavation. In particular, it focuses on the serious impact of tunnel construction and calls for reflection on a wider scale, involving geometric and strategic choices in the design process. Moreover, the high impacts of "standard" building materials used for road construction point out the importance of using secondary raw materials to conserve resources and promote recycling in such sector. Indeed, for each impact category, the road pavement and its materials and works cause on average not more than $1 \%$ of total impacts; on the other hand, tunnel lighting equipment does not provide relevant contributions to ICs.

Table 9 lists the overall A4 impacts of traffic, pavement and structures maintenance, consumption and maintenance of tunnel lighting during the 60-year service life. For the effects of the design traffic, refer to Euro 4 and Euro IV vehicle stages in reference [41]. It is a conservative approach compliant with the current Italian total fleet.

Therefore, this analysis can be correctly defined a "cradle to gate with transportation to work site and use options" study.

Table 9. LCIA-A4 phase.

\begin{tabular}{cccccc}
\hline IC & $\begin{array}{c}\text { Unit of } \\
\text { Measure }\end{array}$ & Traffic & $\begin{array}{c}\text { Pavement and } \\
\text { Structures } \\
\text { Maintenance }\end{array}$ & $\begin{array}{c}\text { Tunnel } \\
\text { Lighting } \\
\text { Consumption }\end{array}$ & $\begin{array}{c}\text { Tunnel } \\
\text { Lighting } \\
\text { Maintenance }\end{array}$ \\
\hline$G W P$ & kg CO eq. & $1.44 \times 10^{8}$ & $1.10 \times 10^{7}$ & $2.03 \times 10^{8}$ & $3.10 \times 10^{8}$ \\
$O D P$ & kg CFC11-eq. & $1.06 \times 10^{1}$ & $1.81 \times 10^{0}$ & $3.60 \times 10^{1}$ & $4.92 \times 10^{1}$ \\
$A P$ & kg SO eq. & $6.26 \times 10^{5}$ & $4.34 \times 10^{4}$ & $7.02 \times 10^{5}$ & $1.05 \times 10^{6}$ \\
$E P$ & kg PO $_{4}^{3-}$ eq. & $2.27 \times 10^{5}$ & $1.18 \times 10^{4}$ & $1.55 \times 10^{5}$ & $2.92 \times 10^{5}$ \\
$P O C P$ & $\mathrm{~kg} \mathrm{C}_{2} \mathrm{H}_{4}$ eq. & $1.64 \times 10^{5}$ & $9.16 \times 10^{3}$ & $1.29 \times 10^{5}$ & $3.03 \times 10^{5}$ \\
$A D P-E$ & $\mathrm{~kg} \mathrm{Sb} \mathrm{eq.}_{A D P-F}$ & $1.95 \times 10^{1}$ & $1.56 \times 10^{1}$ & $2.51 \times 10^{0}$ & $3.42 \times 10^{2}$ \\
\hline $\mathrm{MJ}$ & $7.74 \times 10^{8}$ & $1.40 \times 10^{8}$ & $2.54 \times 10^{9}$ & $3.46 \times 10^{9}$ \\
\hline
\end{tabular}

The bar graph in Figure 4 represents the percentage contributions of A1 to A4 phases of the examined road during its 60-year reference service life. 


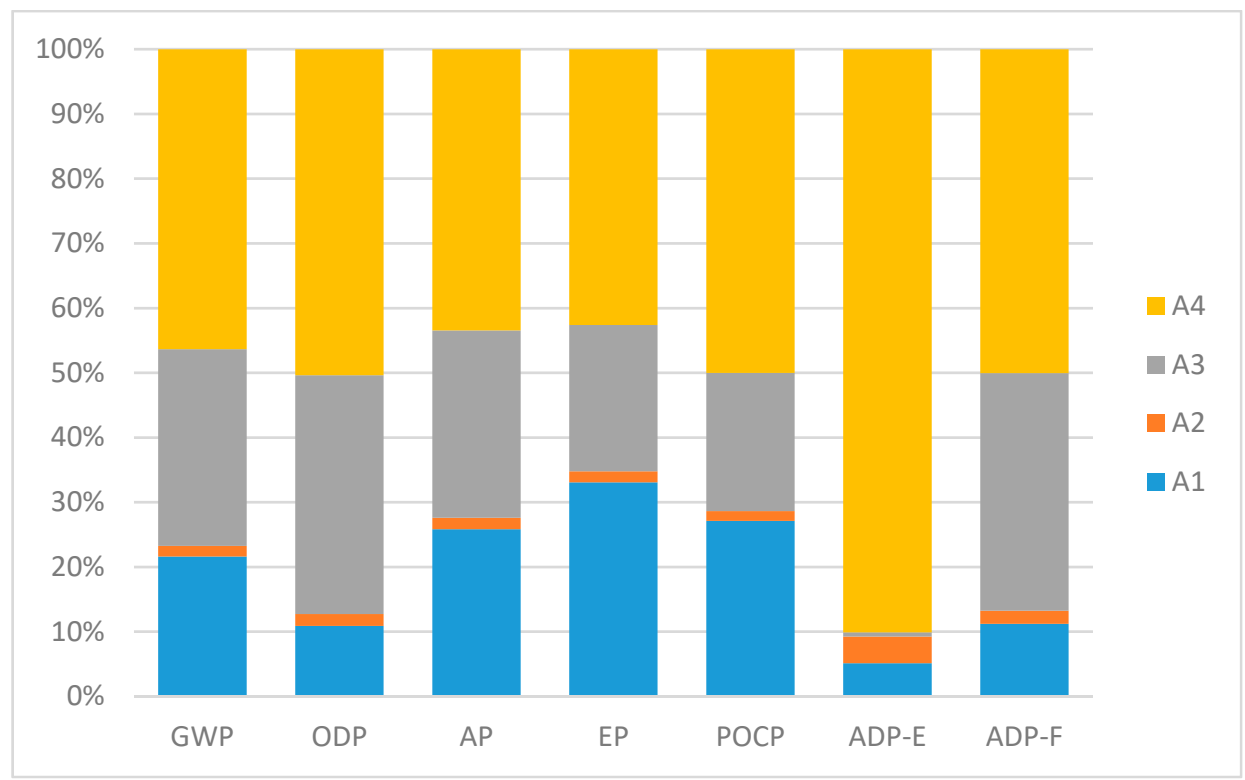

Figure 4. Environmental performances-A1 to A4 phases.

One main observation can be extracted from Figure 4: on average, A4 contributes to $53 \%$ of the overall impact of LCIA. Therefore, the reason why the road has been constructed has overall about half the total impact on the environment: raw materials, fuels, transportation and construction site set-up cause more than $47 \%$ of the overall impacts. The possible future renovation of total fleet (e.g., renovation of current fleet, use of environment-friendly engines and fuels as gas-propelled or electric vehicles) could accentuate the relative impact of the construction stage. Under the present conditions, the obtained results in terms of "transportation" incidence during the service life comply with reference [42]. According to Stripple [42], the emissions of $\mathrm{NO}_{\mathrm{x}}, \mathrm{SO}_{2}$ and $\mathrm{CO}_{2}$ are dominated by the road construction during a 40 year-service life.

As discussed above, the pavement contribution to the total impacts is not relevant; construction of the wearing, binder, base and subbase contribute on average to less than $1 \%$. Even if motorization will change, loads to be transported on the road will not have substantial increases, and pavement contributions will maintain a low incidence. Accordingly, construction and impacts of big structures needed for the road (e.g., bridges and tunnels) will become even more significant.

Given the obtained results, an in-depth impact analysis with more severe traffic conditions has been carried out. According to reference [31], the authors modified the scenario and considered an increase of the road traffic volume. The number of passes of commercial and heavy vehicles varied from 1.5 million/20 years to 10 million/20 years, which is the maximum value expected in the Italian Catalogue of road pavements. The number of cars and mopeds varied accordingly to the traffic spectrum in Table 2. The increase in traffic volume required to adjust the road pavement composition [43] and its related construction and maintenance works in order to achieve the required level of service [44]. The new flexible pavement is composed of $5 \mathrm{~cm}$-thick asphalt wearing course, $8 \mathrm{~cm}$-thick asphalt binder course, $17 \mathrm{~cm}$-thick asphalt base course, and $15 \mathrm{~cm}$-thick granular sub-base.

Table 10 lists the A1 to A4 LCIA results for the amended scenario. The modification of pavement composition affects all the examined phases because it varies both the amount of materials and works (i.e., A1 to A3, upstream phases) before opening up to traffic volume and the maintenance works (i.e., A4). Conversely the increase in traffic volume only affects the use stage (i.e., A4). 
Table 10. A1 to A4 LCIA of the amended scenario.

\begin{tabular}{ccc}
\hline IC & Value & Unit of Measure \\
\hline$G W P$ & $2.12 \times 10^{9}$ & $\mathrm{~kg} \mathrm{CO}_{2}$ eq. \\
$O D P$ & $3.39 \times 10^{2}$ & $\mathrm{~kg} \mathrm{CFC11-eq.}$ \\
$A P$ & $7.19 \times 10^{6}$ & $\mathrm{~kg} \mathrm{SO}_{2}$ eq. \\
$E P$ & $2.01 \times 10^{6}$ & $\mathrm{~kg} \mathrm{PO}_{4}{ }^{-}$eq. \\
$P O C P$ & $2.02 \times 10^{6}$ & $\mathrm{~kg} \mathrm{C}_{2} \mathrm{H}_{4}$ eq. \\
$A D P-E$ & $2.15 \times 10^{3}$ & $\mathrm{~kg} \mathrm{Sb}$ eq. \\
$A D P-F$ & $2.33 \times 10^{10}$ & $\mathrm{MJ}$ \\
\hline
\end{tabular}

With reference to Table 8, the assumed increase in traffic volume $(+667 \%)$ more than triples the overall IC values: the differences range between $+293 \%$ of $E P$ and $+567 \%$ of $A D P-E$.

Figure 5 represents the percentage contributions of A1 to A4 phases of the amended scenario during its 60-year reference service life.

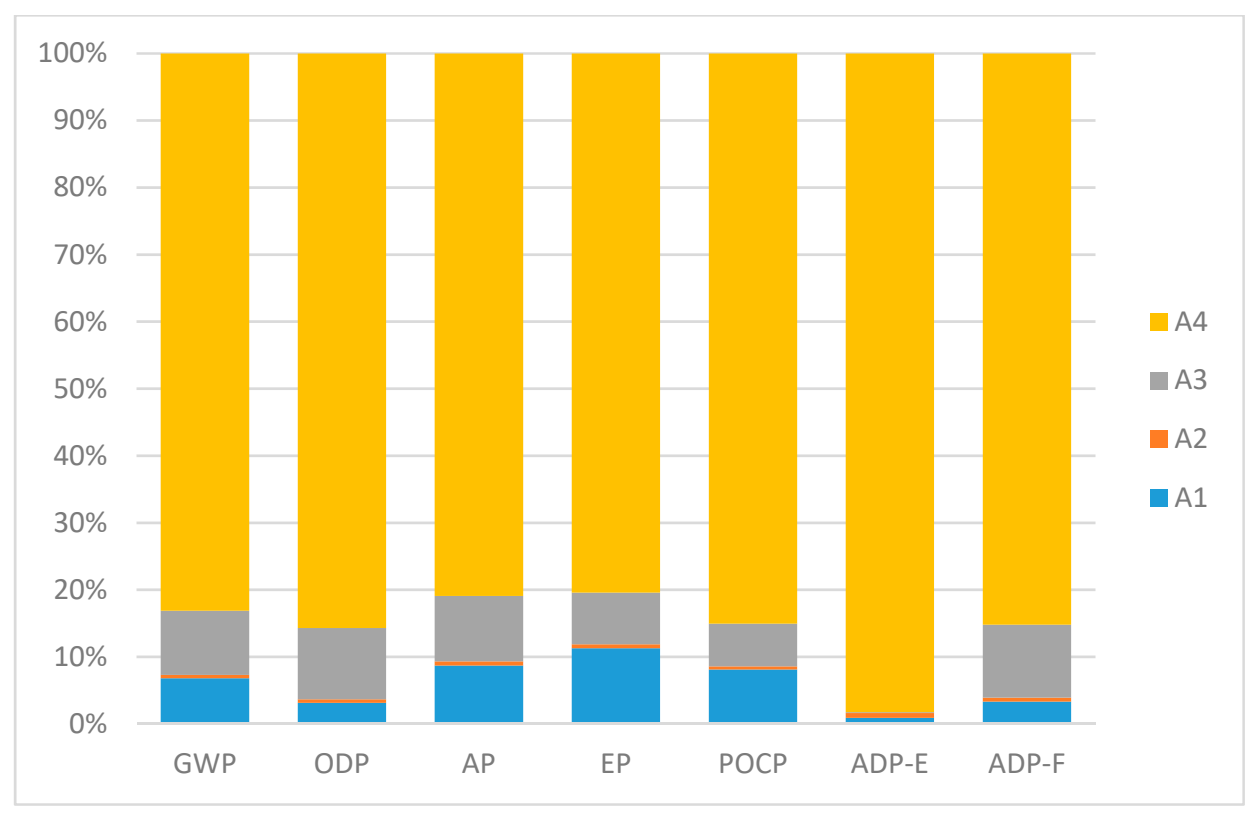

Figure 5. Environmental performances-A1 to A4 phases of the amended scenario.

All trends of the seven examined ICs significantly differ from the original scenario. All significant variations are due to the increase in traffic volume: the impacts of A1 to A3 phases in the amended scenario change by not more than $0.8 \%$ from the original results. An inversion of "until opening to traffic" vs "use" phase has been observed. Indeed, the contribution of A1 to A3 phases to the total impacts has almost halved (e.g., for GWP it decreases from $54 \%$ to $17 \%$, for $A D P-F$ from $50 \%$ to $15 \%$ ). For $A D P-E$, due to its reliance on fuel consumption, the contribution of A4 phase varies from $10 \%$ to $2 \%$.

Given the obtained results, it is possible to identify the breakeven point which represents the number of passes of commercial and heavy vehicles when the "until opening for traffic" impacts match the "use" ones. Figure 6 graphs the findings about the trend of the investigated ICs contributions: the millions of passes of commercial and heavy vehicles are represented on the abscissa, and the percentages of traffic impacts compared to the total value of each parameter are represented on the ordinate. 


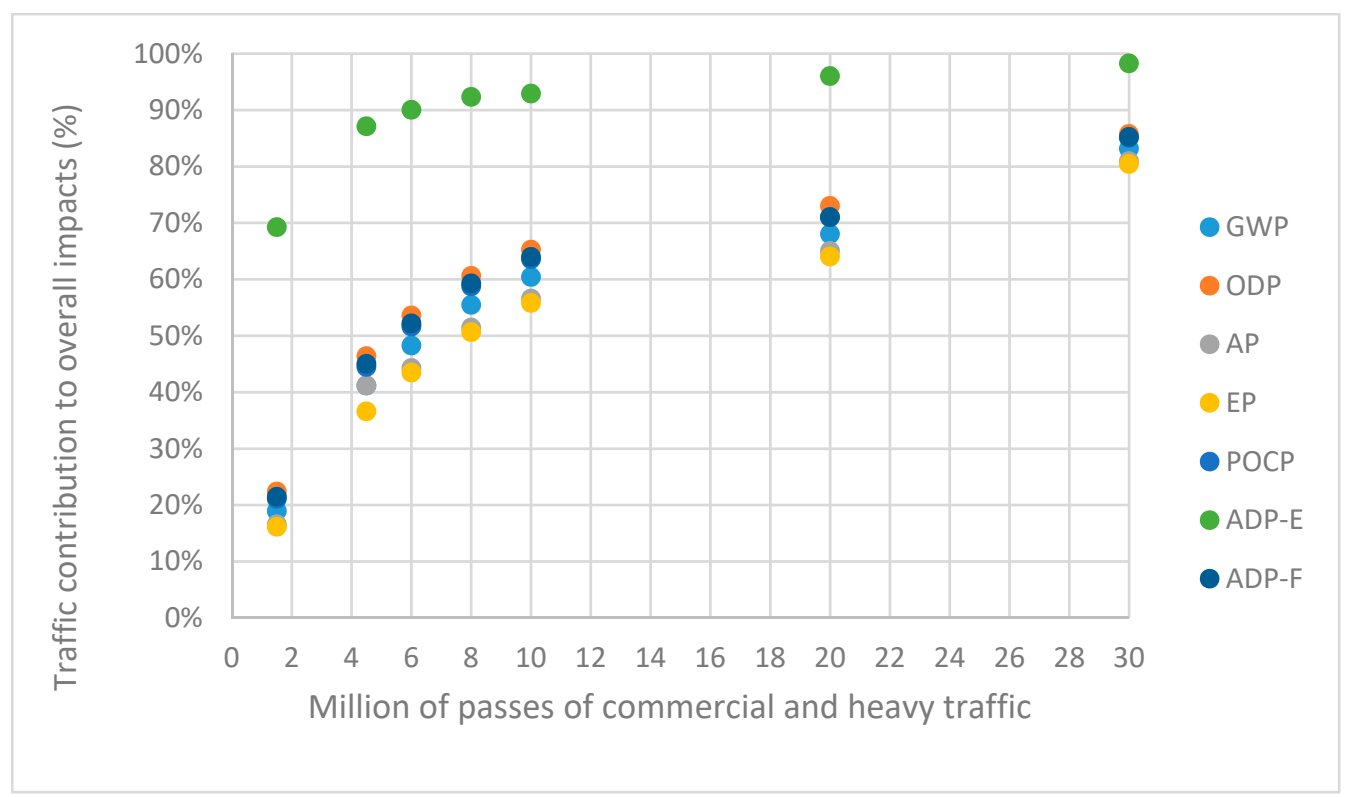

Figure 6. Incidence of traffic volume on traffic contributions to ICs.

According to Figure 6, the expected traffic volume during the overall service life (i.e., 4.5 million passes of commercial and heavy vehicles) causes $87 \%$ of total $A D P-E, 46 \%$ of $O D P, 45 \%$ of total $A D P-F$, $44 \%$ of ODP, $41 \%$ of GWP and $A P$, and $37 \%$ of $E P$. A traffic volume with more than 6 million passes of commercial and heavy vehicles is expected to set the condition for the traffic to contribute to half the overall environmental impacts for $A D P-F, P O C P$, and $O D P$ at least. More than 8 million passes of commercial and heavy vehicles are needed to obtain these results for GWP, EP, and AP.

\section{Discussion}

The obtained numerical results permitted to analyze the environmental impacts of the examined road and its theoretical amended scenario during their 60-year service life.

The quantitative measurements of environmental performances can be used to compare different equivalent proposals when decision-making must be carried out. Indeed, the adopted methodology can be applied to other studies in order to analyze different road projects and facilitate knowledge-based comparative assertions. Although the LCA results are quantitative, however in a (green) public procurement procedure, a decision process should identify the least environmentally damaging choice from a multidimensional perspective [45]. Comparison of all indicators against each other, which is possible only when all the adopted rules and procedures coincide, is not simple because the quantity of data, the multiple unit of measures, the various media to which substances outflow, therefore, a multicriteria decision analysis (MCDA) needs to interpret the results [46] and solve the trade-off between environmental impacts.

Moreover, the comparison of the environmental performances between the original and the amended scenario highlighted that LCA results are specific and each project should be examined under its own boundary system, geographical, social and operational conditions. In the examined case, the decision to construct a route resulted from deepen analysis and assessment of available strategic and theater lift assets, transportation infrastructure, and economic and financial forecasts. Therefore, as a result of the preliminary studies, the road alignment and geometric design cross mountain areas: this determines the structural and technical solutions, which are complex and environmentally-expensive compared to the design traffic, which is relatively low. Therefore, a comprehensive and critical analysis needs to establish the feasibility and sustainability of a road project [47]. To achieve this purpose, MCDA may be applied within the LCA context to aid interpretation of outcomes within the framework of 
sustainable and environmentally-friendly strategies. Indeed, the multicriteria approach would make it possible to reconcile environmental, economic, and social issues and to synthesize their various aspects.

\section{Conclusions}

Life Cycle Analysis has been recently adopted to study the environmental impacts of road transport infrastructure. This approach facilitates the unbiased assessment and critical interpretation of a product. This study compares-for the first time-reliable LCIA results of the environmental impacts of construction and use of an Italian provincial road. The importance of the obtained results is that they allow the identification of processes and technologies responsible for the majority of potential negative impacts on the environment. The examined road is in a mountainous region of the central Italy: therefore, $16.6 \%$ in length is raised on tunnels and viaducts. The design traffic consists of low volume: 4.5 million passes of commercial and heavy vehicles during 60-year reference service life. This condition seriously affects the LCA: the high incidence of "until opening for traffic" phases reflects the complexity of the work. According to the European standard EN 15804, seven impact categories have been assessed: the results showed that the largest part of burdens are from structural materials (e.g., aggregates, concrete, reinforcing steel and earth moving machines), while burdens from the "use" phase (i.e., maintenance, traffic, and lighting) are not more than 50\% throughout the service life. Moreover, the results demonstrated that it is incorrect to consider only one environmental impact to identify the "greenest" process among several alternatives. Indeed, each indicator has a different incidence in terms of its environmental impact, and the contribution of each stage related to the LCA significantly differs from the examined parameters. In particular, the analysis highlighted the need for MCDA to interpret the results and solve the trade-off between environmental impacts.

Finally, it has been found that high traffic volumes may reduce the impacts of "until opening for traffic" to $28 \%$ of the total: when 30 million passes of commercial and heavy vehicles are expected, the "traffic" phase cause on average $82 \%$ of impacts. This demonstrates that there are important differences in the environmental performance of a road varying its design traffic: the same geometric design significantly varies its degree of environmental sustainability. Therefore, the proposed environmental approach should be integrated with social and economic criteria in order to obtain a comprehensive sustainability assessment.

Author Contributions: Conceptualization, L.M.; Data curation, L.M.; Formal analysis, G.T.; Investigation, G.T. and L.M.; Methodology, L.M.; Supervision, A.D.; Visualization, L.M.; Writing—original draft, G.T. and L.M.

Funding: This research received no external funding.

Conflicts of Interest: The authors declare no conflict of interest.

\section{References}

1. Miccoli, S.; Finucci, F.; Murro, R. Urban Green Infrastructures and Social Shared Choices: A Deliberative Valuation Method. Appl. Mech. Mater. 2014, 641-642, 1082-1086. [CrossRef]

2. Miccoli, S.; Finucci, F.; Murro, R. Criteria and Procedures for Regional Environmental Regeneration: A European Strategic Project. Appl. Mech. Mater. 2014, 675-677, 401-405. [CrossRef]

3. Parikka-Alhola, K.; Nissinen, A. Environmental Impacts of Transport as Award Criteria in Public Road Construction Procurement. Int. J. Constr. Manag. 2012, 12, 35-49. [CrossRef]

4. Faith-Ell, C. The Application of Environmental Requirements in Procurement of Road Maintenance in Sweden. Ph.D. Thesis, KTH Land and Water Resources Engineering, Stockholm, Sweden, 2015.

5. Faith-Ell, C.; Balfors, B.; Folkeson, L. The application of environmental requirements in Swedish road maintenance contracts. J. Clean. Prod. 2006, 14, 163-171. [CrossRef]

6. Varnäs, A.; Balfors, B.; Faith-Ell, C. Environmental consideration in procurement of construction contracts: Current practice, problems and opportunities in green procurement in the Swedish construction industry. J. Clean. Prod. 2009, 17, 1214-1222. [CrossRef]

7. Procurement Strategy of the Finnish Road Administration. 2003. Edita Prima Oy, Helsinki. Available online: http:/ / www.doria.fi/bitstream/handle/10024/133234/tie1673.pdf?sequence=1 (accessed on 12 January 2019). 
8. Versteeg, H. Netherlands' experience with sustainable procurement in road construction. International Road Federation. In Proceedings of the IRF Environment Study Day-GPP \& Technology Advancements in the Road Sector, Brussels, Belgium, 20 September 2011.

9. European Commission. EU Green Public Procurement Criteria for Road Design, Construction and Maintenance; European Commission: Brussels, Belgium, 2016.

10. Celauro, C.; Corriere, F.; Guerrieri, M.; Lo Casto, B.; Rizzo, A. Environmental analysis of different construction techniques and maintenance activities for a typical local road. J. Clean. Prod. 2017, 142, 3482-3489. [CrossRef]

11. Balaguera, A.; Carvajal, G.I.; Alberti, J.; Fullana-i-Palmerb, P. Life cycle assessment of road construction alternative materials: A literature review. Resour. Conserv. Recycl. 2018, 132, 37-48. [CrossRef]

12. Kar, S.S.; Behl, A.; Shukla, A.; Jain, P.K. Estimation of Carbon Footprints of Bituminous Road Construction Process. J. Civil Environ. Eng. 2015, 5, 198.

13. Sreedhar, S.; Jichkar, P.; Biligir, K.P. Investigation of Carbon Footprints of Highway Construction Materials in India. Transp. Res. Procedia 2016, 17, 291-300. [CrossRef]

14. Löfgren, B.; Tillman, A.; Rinde, B. Manufacturing actor's LCA. J. Clean. Prod. 2011, 19, 17-18. [CrossRef]

15. Poch, M.; Comas, J.; Rodriguez-Roda, I.; Sànchez-Marrè, M.; Cortès, U. Designing and building real environmental decision support systems. Environ. Model. Softw. 2014, 19, 857-887. [CrossRef]

16. Praticò, F.; Casciano, A.; Tramontana, D. Pavement life-cycle cost and asphalt binder quality: Theoretical and experimental investigation. J. Constr. Eng. Manag. 2010, 137, 99-107. [CrossRef]

17. Moretti, L.; Mandrone, V.; D'Andrea, A.; Caro, S. Comparative "from cradle to gate" Life Cycle Assessments of Hot Mix Asphalt (HMA) Materials. Sustainability 2017, 9, 400. [CrossRef]

18. Azarijafari, H.; Yahia, A.; Ben Amor, M. Life cycle assessment of pavements: Reviewing research challenges and opportunities. J. Clean. Prod. 2016, 112, 2187-2197. [CrossRef]

19. Moretti, L.; Caro, S. Critical analysis of the Life Cycle Assessment of the Italian Cement Industry. J. Clean. Prod. 2017, 152, 198-210. [CrossRef]

20. Moretti, L.; Di Mascio, P.; Bellagamba, S. Environmental, human health and socio-economic effects of cement powders: The multicriteria analysis as decisional methodology. Int. J. Environ. Res. Public Health 2017, 14, 645. [CrossRef] [PubMed]

21. Marzouk, M.; Abdelkader, E.M.; El-zayat, M.; Aboushady, A. Assessing Environmental Impact Indicators in Road Construction Projects in Developing Countries. Sustainability 2017, 9, 843. [CrossRef]

22. Hammervold, J. Towards Greener Road Infrastructure: Life cycle Assessment of Case Studies and Recommendations for Impact Reductions and Planning of Road Infrastructure. Ph.D. Thesis, NTNU, Trondheim, Norway, 2015.

23. Moretti, L.; Mandrone, V.; D'Andrea, A.; Caro, S. Evaluation of the environmental and human health impact of road construction activities. J. Clean. Prod. 2018, 172, 1004-1013. [CrossRef]

24. Sayagh, S.; Venturaa, A.; Hoanga, T.; Franc, D.; Jullien, A. Sensitivity of the LCA allocation procedure for BFS recycled into pavement structures. Resour. Conserv. Recycl. 2010, 54, 348-358. [CrossRef]

25. ECRPD. Energy Conservation in Road Pavement Design, Maintenance and Utilization; Intelligent Energy Europe: Brussels, Belgium, 2010.

26. Gkatzoflias, D.; Kouridis, C.; Ntziachristos, L.; Samaras, Z. COPERT 4 Computer Programme to Calculate Emissions from Road Transport, User manual version 9.0; European Environment Agency: Copenhagen, Denmark, 2012.

27. Goedkoop, M.; Heijungs, R.; Huijbregts, M.; De Schryver, A.; Struijs, J.; van Zelm, R. ReCiPe 2008 a Life Cycle Impact Assessment Method Which Comprises Harmonised Category Indicators at the Midpoint and the Endpoint Level. First Edition Report I: Characterisation. 2009. Available online: https:/ /www.leidenuniv. $\mathrm{nl} / \mathrm{cml} / \mathrm{ssp} /$ publications/recipe_characterisation.pdf (accessed on 12 January 2019).

28. EN (European Committee for Standardization). EN 15804:2012+A1:2013. Sustainability of Construction Works-Environmental Product Declarations-Core Rules for the Product Category of Construction Products; European Committee for Standardization: Brussels, Belgium, 2013.

29. Hoang, T.; Durand, C.; Ventura, A.; Jullien, A.; Laurent, G. A Global Tool for Environmental Assessment of Roads-Application to Transport for Road Building; European Conference of Transport Research Institutes: Hague, The Netherlands, 2005.

30. Ministero delle Infrastrutture e dei Trasporti. Norme Funzionali e Geometriche per la Costruzione Delle Strade; Italian Ministry of Transportation Decreto Ministeriale: Rome, Italy, 2001. 
31. CNR. Catalogo delle Pavimentazioni Stradali. Consiglio Nazionale delle Ricerche, Bollettino Ufficiale 178/95; Consiglio Nazionale delle Ricerche: Rome, Italy, 1995.

32. Wernet, G.; Bauer, C.; Steubing, B.; Reinhard, J.; Moreno-Ruiz, E.; Weidema, B. The ecoinvent database version 3 (part I): Overview and methodology. Int. J. Life Cycle Assess. 2016, 21, 1218-1230. [CrossRef]

33. SimaPro 8.0.5.13; Software SimaPro. Pré; Consultants: Amersfoort, The Netherlands, 2016.

34. Di Mascio, P.; Moretti, L. Concrete vs Asphalt: Pavement and Lighting Costs in Italian Road Tunnels; ACI Special Publication 2018, SP 326, 71; American Concrete Institute: Farmington Hills, MI, USA, 2018.

35. Moretti, L.; Cantisani, G.; Di Mascio, P. Management of road tunnels: Construction, maintenance and lighting costs. Tunn. Undergr. Space Technol. 2016, 51, 84-89. [CrossRef]

36. Moretti, L.; Cantisani, G.; Di Mascio, P.; Caro, S. Technical and economic evaluation of lighting and pavement in Italian road tunnels. Tunn. Undergr. Space Technol. 2017, 65, 42-52. [CrossRef]

37. Ente Nazionale Italiano di Normazione (UNI). UNI 11095:2011: Illuminazione delle Gallerie Stradali; UNI: Milan, Italy, 2011. (In Italian)

38. Ente Nazionale Italiano di Normazione (UNI). UNI 10439:2001: Illuminotecnica—Requisiti Illuminotecnici Delle Strade Con Traffico Motorizzato; UNI: Milan, Italy, 2001. (In Italian)

39. Ente Nazionale Italiano di Normazione (UNI). UNI 11248:2012: Illuminazione Stradale-Selezione Delle Categorie Illuminotecniche; UNI: Milan, Italy, 2012. (In Italian)

40. Ente Nazionale Italiano di Normazione (UNI). UNI EN 13201-2:2004: Illuminazione Stradale_Parte 2: Requisiti Prestazionali; UNI: Milan, Italy, 2004. (In Italian)

41. European Commission. Commission Directive 2002/80/EC of 3 October 2002 Adapting to Technical Progress Council Directive 70/220/EEC Relating to Measures to be Taken against Air Pollution by Emissions from Motor Vehicles; European Commission: Brussels, Belgium, 2002.

42. Stripple, H. Life Cycle Assessment of Road. A Pilot Study for Inventory Analysis, 2nd ed.; Report IVL Swedish Environmental Research Institute: Gothenburg, Sweden, 2001.

43. Di Mascio, P.; Loprencipe, G.; Maggioni, F. Visco-elastic modeling for railway track structure layers. [Modellazione del comportamento visco-elastico degli strati della sede ferroviaria]. Ingegneria Ferroviaria 2014, 69, 207-222.

44. Loprencipe, G.; Pantuso, A. A Specified Procedure for Distress Identification and Assessment for Urban Road Surfaces Based on PCI. Coatings 2017, 7, 65. [CrossRef]

45. Zanghelini, G.M.; Cherubini, E.; Soares, S.R. How Multi-Criteria Decision Analysis (MCDA) is aiding Life Cycle Assessment (LCA) in results interpretation. J. Clean. Prod. 2018, 172, 609-622. [CrossRef]

46. Benoit, V.; Rousseaux, P. Aid for aggregating the impacts in life cycle assessment. Int. J. Life Cycle Assess. 2003, 8, 74-82. [CrossRef]

47. Albuquerque, G.A.; Maciel, P.; Lima, R.M.F.; Magnani, F. Strategic and tactical evaluation of conflicting environment and business goals in green supply chains. IEEE Trans. Syst. Man Cybern. Syst. 2013, 43, 1013-1027. [CrossRef]

(C) 2019 by the authors. Licensee MDPI, Basel, Switzerland. This article is an open access article distributed under the terms and conditions of the Creative Commons Attribution (CC BY) license (http:// creativecommons.org/licenses/by/4.0/). 